Pimmel A., and Claypool, G.

ODP Technical Note 30

\title{
INTRODUCTION TO SHIPBOARD ORGANIC GEOCHEMISTRY ON THE JOIDES Resolution ${ }^{1,2}$
}

A. Pimmel ${ }^{3}$ and G. Claypool ${ }^{4}$

\section{DUTIES OF ORGANIC GEOCHEMISTS AND CHEMISTRY TECHNICIANS}

Organic geochemical capabilities on the JOIDES Resolution have a twofold purpose. The first is to fulfill the hydrocarbon monitoring requirements that have become standard at most sites cored by the Ocean Drilling Program (ODP). The second is to provide measurements of the quantity and quality of organic matter in cored sediments in support of the scientific objectives of ODP.

The main hazard in ocean drilling with respect to safety and pollution prevention is the possibility of encountering a charged reservoir, allowing oil and hydrocarbon gas to escape in large quantities into the sea and the atmosphere (Ocean Drilling Program, 1992). The primary responsibility of the organic geochemist is to provide the operations manager and the co-chief scientists with advice concerning the probable risks of an uncontrolled release of petroleum hydrocarbons. The chemistry technicians' responsibility is to help the organic geochemists in collecting data that will be used for making decisions about safety and pollution prevention.

\section{HYDROCARBON ORIGINS AND OCCURRENCES}

Hydrocarbon generation is the natural result of the maturation of buried organic matter.
${ }^{1}$ Pimmel, A., and Claypool, G., 2001. Introduction to shipboard organic geochemistry on the JOIDES

Resolution. ODP Tech. Note, 30 [Online]. Available from World Wide Web: <http://www-odp.tamu.edu/ publications/tnotes/tn30/

INDEX.HTM>. [Cited YYYY-MM-DD]

${ }^{2}$ See Disclaimer, p. 20

${ }^{3}$ Ocean Drilling Program, 1000

Discovery Drive, College Station TX

77845-9547, USA.

pimmel@odpemail.tamu.edu

${ }^{4} 8910$ West 2nd Avenue, Lakewood

CO 80226, USA. 
Organic matter (organic carbon) in sediments underlying the oceans is derived from different sources (Emeis and Kvenvolden, 1986), including the following:

1. Marine phytoplankton,

2. Phytobentos in shallow water with sufficient light,

3. Bacteria, and

4. Allochtonous (i.e., land derived) material.

The organic carbon produced in the water column varies from $\sim 0.1 \%$ to $5 \%$, depending on various factors such as the following:

1. Oxygen depletion in bottom waters or in sediment as a result of high organic input,

2. Adsorption of certain compounds to mineral particles,

3. Preservation of organic compounds as shell constituents,

4. Changes in the rate of deposition of sediment organic matter,

5. High input of terrigenous organic compounds, which are more stable than organic matter, and

6. Dominant input of argillaceous sediments where oxygenation of pore water is restricted.

Organic matter undergoes changes in composition with increasing burial depth and temperature. The three steps in the transformation of organic matter to petroleum hydrocarbons are termed diagenesis, catagenesis, and metagenesis. The general scheme of evolution of the organic fraction and the hydrocarbons produced is depicted in Figure F1 (Tissot and Welte, 1984). Petroleum hydrocarbons exist as gaseous, liquid, and solid phases, depending on temperature, pressure, burial time, and composition of the system.

\section{$C_{1}-C_{4}$ Hydrocarbons}

$\mathrm{C}_{1}-\mathrm{C}_{4}$ hydrocarbons (methane, ethane, propane, and butane) are found predominantly in the gaseous phase at surface conditions. These hydrocarbon gases, largely methane $\left(C_{1}\right)$, may be generated in significant quantities in sediment, either under near-surface conditions by bacterial action (Claypool and Kaplan, 1974) or at greater depths by thermochemical action (Schoell, 1988).

Biogenic gas (microbial methane) is produced in sulfate-depleted marine sediment where accumulation rates exceed $\sim 50 \mathrm{~m} / \mathrm{m}$.y. and organic matter is preserved. Microbial methane production occurs by reduction of dissolved bicarbonate $\left(\mathrm{CO}_{2}\right)$, and the process competes with sulfate reduction for electrons (hydrogen) generated by the anaerobic oxidation of organic matter. At sedimentation rates slower than $\sim 50 \mathrm{~m} / \mathrm{m}$.y., sulfate is continually replenished by diffusion from overlying seawater until metabolizable organic matter is completely consumed, leaving none for methane generation.

Thermogenic gases $\left(C_{1}-C_{4}\right)$ are produced in sediments at rates that are proportional to temperature. In most ODP holes with normal geothermal gradients $\left(20^{\circ}-50^{\circ} \mathrm{C} / \mathrm{km}\right)$, sediment temperatures are insufficient to produce more than trace amounts of thermogenic gases. High concentrations of thermogenic gases in sediments at shallow depths and low temperatures generally indicate the existence of a hydrocarbon migration pathway. However, it is becoming increasingly recognized
F1. Evolution of organic fraction and the hydrocarbon produced, p. 21 .

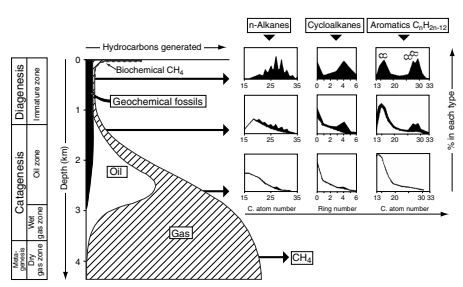




\section{A. Pimmel and G. Claypool}

that the $\mathrm{C}_{2}-\mathrm{C}_{4}$ gases can be produced bacterially along with $\mathrm{C}_{1}$, although not in high concentrations (Vogel et al., 1982; Wiesenburg et al., 1985; Oremland et al., 1988; Feary, Hine, Malone et al., 2000). Either biogenic or thermogenic gas can be hazardous. Either can cause a blowout and catch fire. Biogenic and thermogenic gases usually (but not always) can be distinguished on the basis of chemical and carbon isotopic composition (not available on the JOIDES Resolution). However, it is amount of the gas and the possibility of high-pressure accumulation that poses the hazard, not the mechanism of origin.

\section{$C_{5}$ and Heavier Hydrocarbons}

$\mathrm{C}_{5}$ and heavier hydrocarbons (oil), predominantly liquid, are almost exclusively the product of thermal generation from hydrogen-rich organic matter in deeply buried sediments (oil of microbial origin is unknown). This generation occurs at rates that become quantitatively important only as temperatures reach $90^{\circ}-150^{\circ} \mathrm{C}$ (typically at burial depths of 2500-5000 m for average geothermal gradients). Hydrocarbon gases are generated with the oil, and although they consist largely of methane, they usually also include heavier hydrocarbons. Thermogenic conversion of organic matter to hydrocarbons continues at accelerating rates with increasing depth and temperature until all organic matter, including the oil itself, has been converted largely to methane and carbon-rich residues (Ocean Drilling Program, 1992).

The sources of organic matter can sometimes be inferred on board the JOIDES Resolution from results of geochemical analyses, of which Rock Eval pyrolysis, petrographic investigation of kerogens, and gas chromatography/mass spectrometry (GC/MSD) of solvent extracts are examples (see "Hydrocarbon Monitoring Procedures," p. 3).

\section{HYDROCARBON MONITORING PROCEDURES}

Two general procedures are relied upon to prevent ODP from drilling sediments that might contain hydrocarbon accumulation.

The first is the site selection and review process, in which proposed drill sites with geological factors conducive to hydrocarbon accumulation are either eliminated from the drilling program or relocated to avoid safety problems. Site review is performed by the JOIDES Pollution Prevention and Safety Panel and the Ocean Drilling Program Safety Panel. Some of the factors considered in the site selection and review process include the following:

1. General geologic background,

2. Character of the section to be penetrated (The thickness of sedimentary rock is estimated by seismic data. Thick sections $[\geq 2500$ $\mathrm{m}$ ] are always considered possible progenitors of petroleum.),

3. Petroleum indications in the region,

4. Records of other drilling in the vicinity,

5. Anticipated presence of reservoir rocks,

6. Anticipated presence of source rocks,

7. Anticipated presence of evaporite and undercompacted shales,

8. Temperature-pressure conditions with respect to gas hydrate formation,

9. Probability of traps (anticlinal, faults, pinchout, unconformities, etc.), 


\section{A. Pimmel and g. Claypool

10. Water depth, and

11. Proposed drilling and coring program.

The second procedure is the regular shipboard monitoring of the cores to insure that the sediments being drilled do not contain greater than expected amounts of hydrocarbons. The objective of hydrocarbon monitoring from a safety standpoint is to distinguish potentially hazardous accumulations of hydrocarbons from the background of the normal increase in hydrocarbon content with depth.

The prevailing guideline is that drilling should be stopped if hydrocarbons or hydrocarbon indications that suggest the presence of substantial accumulations of gas and oil are encountered (Ocean Drilling Program, 1992)

Identification of chemical composition and physical properties of any gas or solid petroleum substance is critically important for recognition of the presence or possibility of dangerous accumulations. The composition of gases may enable distinction between biogenic gas and thermogenic gas that has leaked upward from an underlying oil and gas accumulation. However, as indicated earlier, origin and composition are of secondary importance; it is the primary quantity of hydrocarbon gas and possibility of accumulation and trapping that pose potential danger.

The degree of generation of petroleum from source rock is primarily related to the temperature that the source rocks have experienced. Thermal maturity can be estimated from the chemical composition of sediment gases, distribution of solvent-extractable hydrocarbon constituents, pyrolysis assay, and color and reflectance of organic particles.

The temperature history or level of maturity must be known to evaluate the significance of hydrocarbon shows. For this purpose, it is necessary to (1) estimate the current capacity of organic matter to generate hydrocarbon and (2) compare the estimate with the actual presence of hydrocarbons, taking into account factors that could promote migration and accumulation of hydrocarbons.

The degree of organic matter maturation and its capacity to generate hydrocarbons may be estimated by an evaluation of (1) the content of $\mathrm{C}_{2}-\mathrm{C}_{5}$ hydrocarbons relative to methane $\left(\mathrm{C}_{1}\right)$. The $\mathrm{C}_{1} / \mathrm{C}_{2}$ ratio changes from $>10,000$ for immature organic matter to $<100$ for mature organic matter; and (2) the Rock Eval pyrolysis parameters that provide evidence of the presence of migrated hydrocarbons.

Evidence for the presence of migrated hydrocarbons may be discerned by two main factors:

1. A two or three order-of-magnitude increase in the content of hydrocarbons compared to overlying strata; and

2. A discrepancy between hydrocarbon content and maturity of organic matter, as well as total organic carbon (TOC) content and other parameters characterizing expected levels of indigenous hydrocarbons.

The hydrocarbon monitoring program consists of three main elements:

1. Gas analyses performed with the natural gas analyzer (NGA) and "GC3" gas chromatographs (GCs) to determine the composition and concentrations of gases in sediments and with the GC/MSD 
for determination of high molecular weight hydrocarbons in solvent extracts;

2. Visual inspection for oil shows (fluorescence); and

3. Pyrolysis using the Rock Eval for a better determination of source, amount, and maturity of the organic matter.

In addition, some measurement of organic carbon content is required. TOC can be obtained either from the Rock Eval TOC module or from the difference between the total carbon from elemental CHNS analysis and carbonate carbon measured by coulometry.

\section{SHIPBOARD ORGANIC GEOCHEMICAL MEASUREMENTS FOR LEG SCIENTIFIC OBJECTIVES}

In addition to the shipboard measurements used for hydrocarbon monitoring purposes, some basic organic geochemical operations are performed in support of the general scientific objectives of the ODP coring program. Carbonate carbon is used to estimate the calcium carbonate content of cores for sedimentological and lithostratigraphic classification purposes. Organic carbon content (directly or by difference) can provide valuable evidence for ocean paleoenvironmental studies and depositional environment classification. Carbon to nitrogen ratios can be used to infer the nature of the organic matter (e.g., land or aquatic plant material) preserved in cores. Methane content is critical for understanding the basic ionic composition of interstitial waters and inference of diagenetic processes and environments. Molecular organic geochemical analyses such as alkenone unsaturation can used to infer marine paleotemperature information.

\section{HYDROGEN SULFIDE $\left(\mathrm{H}_{2} \mathrm{~S}\right)$ HAZARDS}

Low levels of $\mathrm{H}_{2} \mathrm{~S}$ gas may be encountered in cores in which microbial sulfate reduction is occurring or in cores from hydrothermal vent areas in which seawater sulfate has reacted with high-temperature intrusions. $\mathrm{H}_{2} \mathrm{~S}$ is a highly reactive (and toxic) gas, which is normally maintained at negligible concentrations by rapid reaction with iron or other metals present in the sediment. In some cases, such as iron-deficient carbonate sediments and where gas hydrates or sulfate-rich brines are present, $\mathrm{H}_{2} \mathrm{~S}$ concentrations may be sufficient to cause a toxic gas breathing hazard, especially when cores are being handled in confined or poorly ventilated areas. In these situations, the JOIDES Resolution is equipped with $\mathrm{H}_{2} \mathrm{~S}$ sensors on the rig floor, the core receiving platform, and in the interior core-handling areas. $\mathrm{H}_{2} \mathrm{~S}$ levels of 10-20 ppm should activate audible and visual alarms and bring about an $\mathrm{H}_{2} \mathrm{~S}$ alert. $\mathrm{H}_{2} \mathrm{~S}$ odor is apparent at levels below those detectable by sensors or analytical instruments. If $\mathrm{H}_{2} \mathrm{~S}$ presence is suspected, the hydrocarbon monitoring techniques should include analysis by thermal conductivity detector gas chromatography (NGA) to provide information on concentration levels and any trends of $\mathrm{H}_{2} \mathrm{~S}$ occurrence in cores.

Procedures for responding to an $\mathrm{H}_{2} \mathrm{~S}$ alert are fully described in ODP Technical Note 19, Revised $\mathrm{H}_{2} \mathrm{~S}$ Drilling Contingency Plan (Foss and Julson, 1993 [currently under revision]). 
GAS HYDRATES

Methane quantities in excess of pore water saturation will form a free gas phase or a solid gas hydrate, depending on the pressure and temperature of the sediments. In dealing with cores that have high gas concentrations, it is important to estimate the phase properties of the subsurface methane-water system or the depth to the base of the methane hydrate stability zone. These estimates can be based on calculation methods such as those outlined in the JOIDES Safety Manual (Ocean Drilling Program, 1992) or using software packages available in the ship's library (Sloan, 1998). The organic geochemist and chemistry technicians should be prepared to implement appropriate sample procedures if gas hydrates are encountered in cores.

\section{GAS ANALYSES}

The most common method of hydrocarbon monitoring used in ODP's operation is the analysis of gas samples obtained from either core samples (headspace analysis) or from gas expansion pockets visible through clear plastic core liners (vacutainer analysis).

\section{Headspace Analysis}

In headspace analysis, the composition and concentrations of hydrocarbons are analyzed by GC with the following technique.

A $5-\mathrm{cm}^{3}$ sample (one per core), taken from the core immediately after retrieval on deck, is placed in a $20-\mathrm{cm}^{3}$ glass vial that is sealed with a septum and a crimped metal cap. When consolidated or lithified samples are encountered, chips of material are placed in the vial and sealed. From cores where an interstitial water (IW) sample is obtained, the headspace sample is taken from the top of the section immediately next to the IW sample, whenever possible. The vial is labeled with the core, section, and interval from which the sample was taken. The vial is then placed in an oven at $70^{\circ} \mathrm{C}$ for $30 \mathrm{~min}$. A $5-\mathrm{cm}^{3}(5 \mathrm{~mL})$ volume of gas extracted through the septum is then injected with a glass syringe into a gas chromatograph (GC3 and NGA when the sediment contains high levels of hydrocarbons or nonhydrocarbons such as $\mathrm{CO}_{2}$ and $\mathrm{H}_{2} \mathrm{~S}$ ).

\section{Vacutainer Analysis}

When a core comes on deck, it is checked for gas pockets, bubbles, or frothing within the liner or bulging end caps of sealed core liners. These gas pockets are sampled using a gas sampling device that is a liner penetrator tool equipped with a valve and needle. The gas is transferred into a pre-evacuated, septum-sealed glass tube $\left(20 \mathrm{~cm}^{3}\right)$ or a $50-\mathrm{cm}^{3}$ syringe equipped with a three-way stopcock valve. To sample a void, the device is inserted into the core liner where the void is located. The syringe/ vacutainer is placed on the valve, and the valve is switched open. In case of syringe sampling, note that the stopcock handle is always over the closed port. With the glass vacutainer, one first has to place a needle on the valve and then open the valve by turning the switch so that it is parallel with the needle. After $10 \mathrm{~s}$, the valve is turned back off and the vacutainer is removed. Portions of gas in the syringe/vacutainer are then injected for analysis in either or both the GC3 and NGA. 


\section{Description of Instruments Used for Gas Analyses}

The GC3, a Hewlett Packard (HP) GC model 6890, is used to accurately and rapidly measure the concentrations of methane $\left(C_{1}\right)$, ethane $\left(C_{2}\right)$, ethylene $\left(C_{2}=\right)$, propane $\left(C_{3}\right)$, and propylene $\left(C_{3}=\right)$. The GC3 is configured to use an $8 \mathrm{ft} \times 1 / 8$-in stainless steel packed column filled with HayeSep R porous polymer packing (80/100 mesh). The injector consists of a $1 / 16$-in Valco union with a $7-\mu \mathrm{m}$ screen connected to a Valco-to-Luer lock syringe adaptor. This injector connects to a 10-port Valco valve that is switched pneumatically by a digital valve interface (DVI). The injector temperature is set at $110^{\circ} \mathrm{C}$. Samples are introduced into the GC via a $0.25-\mathrm{cm}^{3}$ sample loop connected to the Valco valve. The valve can be switched automatically to backflush the column. The oven temperature is programmed to be initially at $100^{\circ} \mathrm{C}$ for $5.50 \mathrm{~min}$ then increased to $140^{\circ} \mathrm{C}$ for $4 \mathrm{~min}$ at a rate of $50^{\circ} \mathrm{C} / \mathrm{min}$. Helium is the carrier gas. Initial helium flow on the column is $30 \mathrm{~mL} / \mathrm{min}$. Flow is then ramped to $80 \mathrm{~mL} / \mathrm{min}$ after 3 min to accelerate elution of $\mathrm{C}_{3}$ and $\mathrm{C}_{3}=$. The run time is $10.30 \mathrm{~min}$. The GC is equipped with a flame ionization detector (FID) set at $250^{\circ} \mathrm{C}$. The GC is also equipped with an electronic pressure control (EPC) module to control the overall flow into the GC.

The NGA is an HP 6890 multivalve, multicolumn GC. It is equipped with both thermal conductivity (TCD) and FID detectors. The multiplevalve switching system is used to direct flows through various sample loops and columns. Helium is used as the carrier gas. Four columns are used sequentially to provide rapid partitioning and measurement of $\mathrm{N}_{2}$, $\mathrm{O}_{2}, \mathrm{CO}_{2}, \mathrm{H}_{2} \mathrm{~S}, \mathrm{CS}_{2}$, and $\mathrm{C}_{1}-\mathrm{C}_{10}$ hydrocarbons (12 min run). The multicolumn system is composed of a 6 -in stainless steel column packed with Poropak T (50/80 mesh) in line with a 3 -ft column packed with molecular sieve $13 \times(60 / 80 \mathrm{mesh})$, a 6 -ft stainless steel column packed with 80/100 mesh Haysep R (acid washed), and a $60 \mathrm{~m} \times 0.32 \mathrm{~mm}$ capillary column coated with a 1- $\mu \mathrm{m}$ film thickness of DB-1 (J\&W, Inc.). The injection is performed via a $1 / 16$-in Valco union connected to a Valco-toLuer lock syringe adaptor. This injector connects to a six-port Valco valve (V1) switched pneumatically by a DVI. When V1 is in the LOAD position, samples will be introduced onto the entire set of columns via three sample loops $\left(0.25 \mathrm{~cm}^{3}, 1 \mathrm{~cm}^{3}\right.$, and $\left.0.5 \mathrm{~cm}^{3}\right)$. When V1 is in the INJECT position, the sample will be loaded onto the capillary column for separation of $\mathrm{C}_{1}$ to $\mathrm{C}_{7}$ hydrocarbons. Valve 2 (V2) is a four-port Valco valve that can be switched (using a DVI) to backflush the capillary column. Valve 3 (V3) is an eight-port Valco valve connected to a 1$\mathrm{cm}^{3}$ sample loop and the HayeSep R column, which is used to separate air and methane from $\mathrm{CO}_{2}$, ethylene, ethane, $\mathrm{H}_{2} \mathrm{~S}$, propylene, and propane. After propane has eluted, V3 is switched OFF to backflush the Haysep column. Valve 4 (V4) is a 10-port Valco valve connected to a $0.5-\mathrm{cm}^{3}$ sample loop and the Poropak $\mathrm{T}$ and molecular sieve columns, which are used to separate $\mathrm{N}_{2}, \mathrm{O}_{2}$, methane, and CO. Valve 4 is switched OFF immediately after V3 is opened to backflush the columns. The chromatographic separation on the TCD portion of the GC is carried out isothermally at $80^{\circ} \mathrm{C}$. This separates $\mathrm{O}_{2}, \mathrm{~N}_{2}, \mathrm{C}_{1}, \mathrm{C}_{2}, \mathrm{C}_{2}=, \mathrm{H}_{2} \mathrm{~S}, \mathrm{C}_{3}$ and $\mathrm{C}_{3}=$. The hydrocarbon separation on the FID portion of the GC system is carried out isothermally at $50^{\circ} \mathrm{C}$. The FID routinely detects $\mathrm{C}_{1}$ to $\mathrm{C}_{7}$ but can also separate "out" through $\mathrm{C}_{10}$. The TCD injector and detector temperatures are $80^{\circ}$ and $201^{\circ} \mathrm{C}$, respectively, and the corresponding 
temperatures for the FID are $80^{\circ}$ and $250^{\circ} \mathrm{C}$, respectively. The NGA is equipped with two EPC modules.

An HP ChemStation computer data acquisition and analysis system is used to integrate and store the results of the gas measurements. Chromatographic responses are calibrated against preanalyzed standards, and the gas contents are reported in parts per million.

\section{Significance of Gas Data for Safety Consideration and Scientific Interpretation}

For safety consideration, gas composition is commonly expressed as $\mathrm{C}_{1} / \mathrm{C}_{2}$ ratio (obtained from the GC data) and plotted vs. depth. This ratio is generally used to get rapid information about the origin of the hydrocarbons (i.e., to distinguish between biogenic gas and gas migrated from a deeper source of thermogenic hydrocarbons). When high amounts of $C_{1}$ are present $(>10,000 \mathrm{ppm})$, very high $C_{1} / C_{2}$ ratios indicate a gas $\left(\mathrm{C}_{1}\right)$ formation by biological processes. On the other hand, the occurrence of major amounts of $\mathrm{C}_{2}$ (to $\mathrm{C}_{5}$ ) in shallow depths is associated with thermogenic hydrocarbon generation. When interpreting the $\mathrm{C}_{1} / \mathrm{C}_{2}$ ratios, it has to be considered, however, that minor amounts of $\mathrm{C}_{2}$ (and $\mathrm{C}_{3}, \mathrm{C}_{4}$, and $\mathrm{C}_{5}$ ) can also be generated in situ during early (low temperature) diagenesis of organic matter. The importance of this process increases with increasing burial depth, resulting in a consistent ("normal") decrease in $C_{1} / C_{2}$ with increasing temperature. The relationship of $C_{1} / C_{2}$ and sediment temperature (Fig. F2) can be used as one criterion to evaluate the "normal" vs. "anomalous" nature of the hydrocarbon occurrence. Anomalously low $C_{1} / C_{2}$ ratios suggest the presence of migrated thermogenic hydrocarbons (Ocean Drilling Program, 1992).

The $C_{1} / C_{2}$ vs. temperature guidelines developed by the JOIDES Safety Panel (Ocean Drilling Program, 1992) were based on analysis of vacutainer or gas expansion pocket samples. Rudy Stein and others adapted and calibrated the $C_{1} / C_{2}$ vs. temperature diagram (Fig. F2) for headspace analysis (Shipboard Scientific Party, 1995).

Figure $\mathbf{F} 2$ includes a pattern that approximately separates anomalous vs. normal $C_{1} / C_{2}$ ratios. Also shown by the two lines is the approximate influence of different levels of organic carbon content. Headspace and vacutainer techniques generally give slightly different results, especially at shallow depths. Vacutainer $\mathrm{C}_{1} / \mathrm{C}_{2}$ ratios are higher than headspace ratios because the vacutainer technique retains more of the methane, but the overall trends should be similar.

Figure F3 shows the separation pattern of normal vs. anomalous zones for both headspace and vacutainer techniques for Leg 151 Hole $909 \mathrm{C}$. At Site 909 , the headspace $C_{1} / C_{2}$ ratios show the normal general decrease with depth and temperature, from values of $>10,000$ in shallow depths to a value of $\sim 50$ at $1061 \mathrm{mbsf}$ (or $93^{\circ} \mathrm{C}$ in temperature). Vacutainer $C_{1} / C_{2}$ ratios are slightly lower (19) but show the same trend. Despite heavy hydrocarbon $\left(\mathrm{C}_{2}-\mathrm{C}_{7}\right)$ occurrence after $700 \mathrm{msbf}$ (or $60^{\circ} \mathrm{C}$ ), their smooth increase with depth was normal and drilling was continued without incident until 1061.8 msbf. A sharp change in the hydrocarbons (abrupt increase of $\mathrm{C}_{3}-\mathrm{C}_{7}$ ) and other geological observations resulted in the termination of drilling of Hole 909C.

"Appendix A," p. 15, describes the procedure used to inject a gas sample into the GC3 and NGA. "Appendix B," p. 17, describes the pro-
F2. $\mathrm{C}_{1} / \mathrm{C}_{2}$ ratios vs. sediment temperature diagram, p. 22.

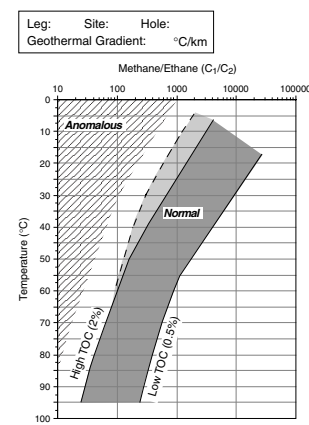

F3. $\mathrm{C}_{1} / \mathrm{C}_{2}$ ratios vs. sediment temperature diagram, Hole 909C, p. 23.

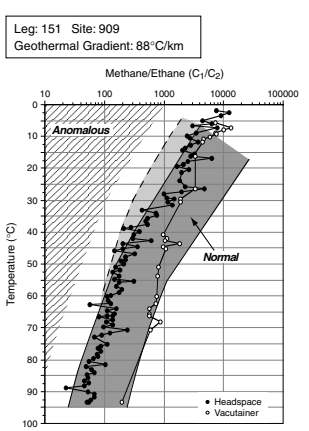




\section{A. Pimmel and G. Claypool}

cedure used to send gas data to the Janus database. "Appendix C," p. 18, describes the features of the GAR program used to monitor gas data in real time.

\section{SOLVENT EXTRACTION AND GAS CHROMATOGRAPHY/MASS SPECTROMETRY}

When cores are suspected to contain migrated petroleum (because of fluorescence, anomalous $C_{1} / C_{2}$ ratios, or other evidence), it may be useful to determine if the extractable organic matter in the cores has a molecular distribution that resembles petroleum. This can be done by extracting a small amount of dried sediment sample with hexane or methylene chloride (depending on the technique used), concentrating the extract solution to a small volume, and analyzing the extract using the GC/MSD.

To prepare the solvent extract, one can use, for example, the method described below.

Crushed, freeze-dried sediment (500 $\mathrm{mg}$ sample) is weighed and transferred into 2-dram screw-cap vials with Teflon-lined caps. Normal hexane $\left(n-\mathrm{C}_{6} \mathrm{H}_{14} ; 2 \mathrm{~mL}\right)$ and methanol $\left(\mathrm{CH}_{3} \mathrm{OH} ; 2 \mathrm{~mL}\right)$ are added to the vial, and the suspension is shaken occasionally for $\sim 2 \mathrm{hr}$ (if the sample is freeze-dried, methanol should not be used for extraction). The clear supernatant solution is pipetted into a second vial $(2 \mathrm{~mL})$ and the extraction is repeated with another $1-\mathrm{mL}$ aliquot of $n-\mathrm{C}_{6} \mathrm{H}_{14}$. The combined extract is evaporated to near dryness under a nitrogen blowdown at $\sim 40^{\circ} \mathrm{C}$ and is then taken up in $n$-hexane to a volume of $50 \mu \mathrm{L}$. A 1- to 8- $\mu \mathrm{L}$ sample is then injected in the GC/MSD.

The GC/MSD is an HP 5973 system that consists of a HP 6890 GC, a mass selective detector, and an HP 7683 automatic liquid sampler (ALS). The 6890 GC is equipped with an EPC split-splitless inlet and has been fitted with an HP-5MS 5\% phenyl methyl siloxane capillary column with dimensions of $30 \mathrm{~m} \times 250 \mu \mathrm{m}$ and a film thickness of $0.25 \mu \mathrm{m}$. The column enters the MSD through a heated conduit called the GC/ MSD interface. Injections are done automatically using the ALS. The MSD itself (referred to as the analyzer) is composed of an electron impact ion source, mass filter, detector, analyzer heater, and radiators. Helium is used as the carrier gas. An alkenone method developed during Leg 185 can be used for both qualitative and quantitative analyses. The run time is $78 \mathrm{~min}$.

In this method, the GC parameters are as follows:

Injection volume $=1 \mu \mathrm{L}$,

Front inlet temperature $=300^{\circ} \mathrm{C}$,

Splitless injection mode $=$ selected

Column flow $=1 \mathrm{~mL} / \mathrm{min}$ (constant mode selected),

Column outlet $=$ MSD (vacuum),

Initial oven temperature $=40^{\circ} \mathrm{C}$ (hold $2 \mathrm{~min}$ ),

Oven ramp $=20^{\circ} \mathrm{C} / \mathrm{min}$ to $130^{\circ} \mathrm{C}$ (no hold) then $4^{\circ} \mathrm{C} / \mathrm{min}$ to $320^{\circ} \mathrm{C}$ (hold $20 \mathrm{~min}$ ) then $70^{\circ} \mathrm{C} / \mathrm{min}$ to $40^{\circ} \mathrm{C}$,

Thermal AUX2 temperature $=280^{\circ} \mathrm{C}$ (used for heating MSD transfer line), and

RTE integrator $=$ data analysis selected.

In this method, the MSD acquisition parameters are as follows: 


\section{A. Pimmel and g. Claypool

Tune file $=$ ATUNE.A,

Acquisition mode $=$ scan,

Solvent delay $=5 \mathrm{~min}$,

Electron multiplier offset $=0$,

Low mass $=27$,

High mass $=500$,

Threshold $=500$,

Sampling = 2,

MSD quadropole temperature $=150^{\circ} \mathrm{C}$, and

MSD source temperature $=230^{\circ} \mathrm{C}$.

An HP MS ChemStation computer data acquisition and analysis system is used to run the GC/MSD. Chromatographic response is calibrated against a preanalyzed high molecular weight (HWM) Supelco standard (containing $\mathrm{C}_{10}$ to $\mathrm{C}_{36}$ hydrocarbons), and the concentrations are reported in nanograms per liter.

\section{FLUORESCENCE}

Fluorescence measurements can indicate the presence of aromatic compounds in petroleum and its products. Fluorescence of pyrolysis products (bitumen) is an approximate indicator of the petroleum potential of a sediment.

Most of the time, when the gas data suggest a thermogenic origin, fluorescence is measured on the bulk samples taken from each core. A small amount of sample taken from the headspace sample is placed in an aluminum pan, and a few milliliters of trichloroethane are added. The sample stays in the trichloroethane for 15-30 min, and the fluorescence intensity is estimated by the ODP operations manager or organic chemist under an ultraviolet lamp. Strong light yellow fluorescence of the sediment and a white-blue fluorescence of the fluid ("cut fluorescence") may indicate the presence of liquid hydrocarbons (Shipboard Scientific Party, 1995).

\section{CHNS ANALYSIS}

Elemental analyses of total nitrogen and carbon (and sulfur) is performed to provide carbonate and organic carbon and to get some idea of the composition of the organic matter (i.e., to distinguish between marine and terrigenous sources, based on total organic carbon/total nitrogen $[\mathrm{C} / \mathrm{N}]$ ratios).

The total nitrogen, carbon, and sulfur are determined using a CHNS analyzer, model NA 1500 from Carlo Erba Instruments. For the CHNS analysis, freeze-dried and crushed samples are weighed (5-10 mg) and mixed with an oxidizer (vanadium pentoxide $\left[\mathrm{V}_{2} \mathrm{O}_{5}\right]$ ) in a tin capsule, which is then combusted in a reactor at $1000^{\circ} \mathrm{C}$. The sample and container melt, and the tin promotes a violent reaction (flash combustion) in a temporarily enriched oxygen atmosphere. The combustion products $\mathrm{CO}_{2}, \mathrm{SO}_{2}$, and $\mathrm{NO}_{2}$ are carried by a constant flow of carrier gas (helium) that passes through a glass column packed with an oxidation catalyst of tungsten trioxide $\left(\mathrm{WO}_{3}\right)$ and a copper reducer, both kept at $1000^{\circ} \mathrm{C}$. At this temperature, the nitrogen oxide is reduced to $\mathrm{N}_{2}$. The $\mathrm{N}_{2}, \mathrm{CO}_{2}$, and $\mathrm{SO}_{2}$ are then transported by the helium to, and separated 


\section{A. Pimmel and G. Claypool}

\section{SHIPBOARD ORGANIC GEOCHEMISTRY}

by, a 2-m-long packed column (Poropak Q/S 50/80 mesh) and quantified with a TCD (set at $290^{\circ} \mathrm{C}$.)

The chromatographic responses are calibrated against preanalyzed standards, and the CHNS elemental contents are reported in weight percent. Eager 200 software is used for running the equipment, storing the data, and for postrun analysis.

TOC is usually calculated by difference between the total carbon (TC) value determined by the Carlo Erba CHNS and the carbonate carbon (IC) determined with the coulometer Model 5030 as described below.

The coulometer provides an absolute determination of carbon dioxide $\left(\mathrm{CO}_{2}\right)$, which is used to determine carbonate weight percent in sediment samples. Freeze-dried, crushed samples $(\sim 10 \mathrm{mg})$ are acidified (with $2-\mathrm{N} \mathrm{HCl}$ ) in a glass tube to convert the carbonate to $\mathrm{CO}_{2}$. Air that has been scrubbed of $\mathrm{CO}_{2}$ carries the generated $\mathrm{CO}_{2}$ through another scrubber to remove any $\mathrm{SO}_{2}$ and then to the coulometer cell. The coulometer cell contains two compartments that are partitioned with a ceramic frit. The larger compartment is filled with monoethanolamine (ME), a colorimetric indicator, and contains a platinum cathode. The smaller compartment is filled with a proprietary solution (anode solution) and contains a silver anode. In the coulometer cell, the $\mathrm{CO}_{2}$ is absorbed, reacting with the ME to form a titrable acid that causes the color to fade. A photodetection cell monitors the change in the solution color. As the percent transmittance $(\mathrm{T})$ increases, the titration current is activated to generate base at a proportional rate. When the solution returns to its original color $(\mathrm{T}=29 \%)$, the current stops indicating and the titration ends. A carbon program developed using Labview software reads the count value from the red display on the coulometer at the end of the titration and provides the IC and $\mathrm{CaCO}_{3}$ (in weight percent) of the samples analyzed.

Organic $\mathrm{C} / \mathrm{N}$ ratios can be used to help identify the origin of the organic matter in sediments. (Shipboard Scientific Party, 1998). C/N ratios of 5-8 indicate unaltered algal organic matter, whereas $\mathrm{C} / \mathrm{N}$ ratios of 25-35 indicate fresh land-derived organic matter. (Emerson and Hedges, 1988; Meyers, 1994). Interpretation of $\mathrm{C} / \mathrm{N}$ ratios needs to be done with caution. Low $\mathrm{C} / \mathrm{N}$ values in sediment containing low organic carbon may be biased by the tendency of clay to absorb ammonium ions generated during the degradation of organic matter (Müller, 1977). Preferential loss of nitrogen-rich, proteinaceous matter can elevate the $\mathrm{C} / \mathrm{N}$ ratios of algal organic matter during settling to the seafloor (Meyers, 1997).

\section{ROCK EVAL PYROLYSIS}

Rock Eval pyrolysis is used to identify the type and maturity of organic matter and to detect petroleum potential in sediments. Rock Eval pyrolysis is done using the Delsi-Nermag Rock Eval II Plus TOC module. Samples chosen to be measured on the Rock Eval are usually subsampled from the freeze-dried material previously crushed for analyses on the coulometer and CNS.

The Rock Eval (RE) pyrolysis method consists of a programmed temperature heating (in a pyrolysis oven) in an inert atmosphere (helium) of a small sample $(\sim 100 \mathrm{mg})$ to quantitatively and selectively determine (1) the free hydrocarbons contained in the sample and (2) the hydrocarbon- and oxygen-containing compounds $\left(\mathrm{CO}_{2}\right)$ that are volatilized dur- 


\section{A. Pimmel and G. Claypool}

\section{SHIPBOARD ORGANIC GEOCHEMISTRY}

ing the cracking of the unextractable organic matter in the sample (kerogen).

The pyrolysis oven temperature program is as follows: for $3 \mathrm{~min}$, the oven is kept isothermally at $300^{\circ} \mathrm{C}$ and the free hydrocarbons are volatilized and measured as the $S_{1}$ peak (detected by FID). The temperature is then increased from $300^{\circ}$ to $550^{\circ} \mathrm{C}$ (at $25^{\circ} \mathrm{C} / \mathrm{min}$ ). This is the phase of volatilization of the very heavy hydrocarbons compounds $\left(>\mathrm{C}_{40}\right)$ as well as the cracking of nonvolatile organic matter. The hydrocarbons released from this thermal cracking are measured as the $S_{2}$ peak (by FID). The temperature at which $S_{2}$ reaches its maximum depends on the nature and maturity of the kerogen and is called $T_{\max }$. The $\mathrm{CO}_{2}$ issued from kerogen cracking is trapped in the $300^{\circ}-390^{\circ} \mathrm{C}$ range. The trap is heated, and $\mathrm{CO}_{2}$ is released and detected on a TCD during the cooling of the pyrolysis oven ( $S_{3}$ peak).

In summary, the four basic parameters obtained by pyrolysis (Fig. F4; from Tissot and Welte, 1984) are as follows:

$\mathrm{S}_{1} \quad=$ the amount of free hydrocarbons (gas and oil) in the sample (in milligrams of hydrocarbon per gram of rock). If $S_{1}>1 \mathrm{mg} /$ $\mathrm{g}$, it may be indicative of an oil show. $S_{1}$ normally increases with depth. Contamination of samples by drilling fluids and mud can give an abnormally high value for $S_{1}$.

$\mathrm{S}_{2}=$ the amount of hydrocarbons generated through thermal cracking of nonvolatile organic matter. $\mathrm{S}_{2}$ is an indication of the quantity of hydrocarbons that the rock has the potential of producing should burial and maturation continue. This parameter normally decreases with burial depths $>1 \mathrm{~km}$.

$\mathrm{S}_{3}=$ the amount of $\mathrm{CO}_{2}$ (in milligrams $\mathrm{CO}_{2}$ per gram of rock) produced during pyrolysis of kerogen. $S_{3}$ is an indication of the amount of oxygen in the kerogen and is used to calculate the oxygen index (see below). Contamination of the samples should be suspected if abnormally high $\mathrm{S}_{3}$ values are obtained. High concentrations of carbonates that break down at lower temperatures than $390^{\circ} \mathrm{C}$ will also cause higher $\mathrm{S}_{3}$ values than expected.

$T_{\max }=$ the temperature at which the maximum release of hydrocarbons from cracking of kerogen occurs during pyrolysis (top of $\mathrm{S}_{2}$ peak). $T_{\max }$ is an indication of the stage of maturation of the organic matter.

The RE II apparatus can also be used to determine the TOC of the sample by oxidizing (in an oxidation oven kept at $600^{\circ} \mathrm{C}$ ) the organic matter remaining in the sample after pyrolysis (residual organic carbon). The TOC is then determined by adding the residual organic carbon detected to the pyrolyzed organic carbon, which in turn is measured from the hydrocarbon compounds issuing from pyrolysis.

The type and maturity of organic matter in petroleum source rocks can be characterized from Rock Eval pyrolysis data (see Fig. F5; from Emeis and Kvenvolden, 1986. This figure has been adapted for marine sediments cored by ODP.) using the following parameters:

$\mathrm{HI}=$ hydrogen index $\left(\mathrm{HI}=\left[100 \times \mathrm{S}_{2}\right] / \mathrm{TOC}\right) . \mathrm{HI}$ is a parameter used to characterize the origin of organic matter. Marine organisms and algae, in general, are composed of lipid- and protein-rich
F4. Example of Rock Eval trace, p. 24.

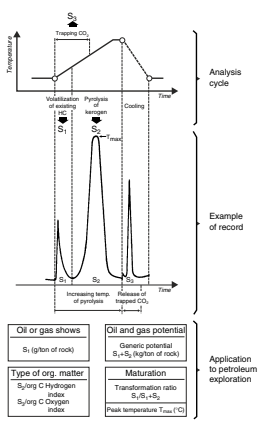

F5. HI/OI plot from Rock Eval pyrolysis data, p. 25.

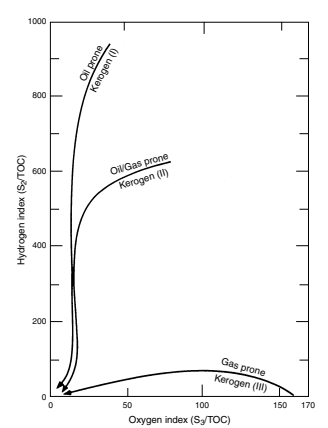




\section{A. Pimmel and g. Claypool}

organic matter, where the ratio of $\mathrm{H}$ to $\mathrm{C}$ is higher than in the carbohydrate-rich constituents of land plants. HI typically ranges from $\sim 100$ to 600 in geological samples.

$\mathrm{OI}=$ oxygen index $\left(\mathrm{OI}=\left[100 \times \mathrm{S}_{3}\right] / \mathrm{TOC}\right)$. OI is a parameter that correlates with the ratio of $\mathrm{O}$ to $\mathrm{C}$, which is high for polysacharriderich remains of land plants and inert organic material (residual organic matter) encountered as background in marine sediments. OI values range from near 0 to $\sim 150$.

$\mathrm{PI}=$ production index $\left(\mathrm{PI}=\mathrm{S}_{1} /\left[\mathrm{S}_{1}+\mathrm{S}_{2}\right]\right)$. PI is used to characterize the evolution level of the organic matter.

$\mathrm{PC}=$ pyrolyzable carbon $\left(\mathrm{PC}=0.083 \times\left[\mathrm{S}_{1}+\mathrm{S}_{2}\right]\right)$. PC corresponds to carbon content of hydrocarbons volatilized and pyrolyzed during the analysis.

Maturation of the organic matter can be estimated by (1) the location of $\mathrm{HI}$ and OI on Figure F5 (the arrows point toward increasing maturation) and (2) $T_{\max }$ range. $T_{\max }=400^{\circ}-430^{\circ} \mathrm{C}$ represents immature organic matter; $T_{\max }=435^{\circ}-450^{\circ} \mathrm{C}$ represents mature or oil zone; $T_{\max }>450^{\circ} \mathrm{C}$ represents the overmature zone.

Rock Eval pyrolysis is not normally used to make real-time drilling decisions because of the lengthy sample preparation, running, and interpretation time. 


\section{REFERENCES}

Claypool, G.E., and Kaplan, I.R., 1974. The origin and distribution of methane in marine sediments. In Kaplan, I.R. (Ed.), Natural Gases in Marine Sediments: New York (Plenum), 99-139.

Emeis, K.-C., and Kvenvolden, K.A., 1986. Shipboard organic geochemistry on JOIDES Resolution. ODP Tech. Note, 7.

Emerson, S., and Hedges, J.I., 1988. Processes controlling the organic carbon content of open ocean sediments. Paleoceanography, 3:621-634.

Feary, D.A., Hine, A.C., Malone, M.J., et al., 2000. Proc. ODP, Init. Repts., 182 [CDROM]. Available from: Ocean Drilling Program, Texas A\&M University, College Station, TX 77845-9547, U.S.A.

Foss, G.N., and Julson, B.D., 1993. Revised hydrogen sulfide drilling contingency plan-JOIDES Resolution. ODP Tech. Note, 19.

Meyers, P.A., 1994. Preservation of elemental and isotopic source identification of sedimentary organic matter. Chem. Geol., 144:289-302.

- 1997. Organic geochemical proxies of paleoceanographic, paleolimnologic, and paleoclimatic processes. Org. Geochem., 27:213-250.

Müller, P.J., 1977. C/N ratios in Pacific deep sea sediments: effect of inorganic ammonium and organic nitrogen compounds sorbed by clays. Geochim. Cosmochim. Acta, 41:765-776.

Ocean Drilling Program, 1992. Guidelines for pollution prevention and safety. JOIDES J., 18 (Spec. Iss. 7) 1-24.

Oremland, R.S., Whiticar, M.J., Strohmaier, F.E., and Kiene, R.P., 1988. Bacterial ethane formation from reduced, ethylated sulfur compounds in anoxic sediments. Geochim. Cosmochim. Acta, 52:1895-1904.

Schoell, M., 1988. Multiple origins of methane in the earth. Chem. Geol., 71:1-10.

Shipboard Scientific Party, 1995. Site 909. In Myhre, A.M., Thiede, J., Firth, J.V., et al., Proc. ODP, Init. Repts., 151: College Station, TX (Ocean Drilling Program), 159-220.

, 1998. Site 1075. In Wefer, G., Berger, W.H., and Richter, C., et al., Proc. ODP, Init. Repts., 175: College Station, TX (Ocean Drilling Program), 49-86.

Sloan, E.D., 1998. Clathrate Hydrates of Natural Gases, 2nd Edition: New York (Marcel Dekker, Inc.).

Tissot, B.P., and Welte, D.H., 1984. Petroleum Formation and Occurrence ( $2^{\text {nd }}$ ed.): Heidelberg (Springer-Verlag).

Vogel, T.M., Oremland, R.S., and Kvenvolden, K.A., 1982. Low-temperature formation of hydrocarbon gases in San Francisco Bay sediment (California). Chem. Geol., 37:289-298.

Wiesenburg, D.A., Brooks, J.M., and Bernard, B.B., 1985. Biogenic hydrocarbon gases and sulfate reduction in the Orca Basin Brine. Geochim. Cosmochim. Acta, 49:20692080. 
APPENDIX A

\section{How to Run a Headspace (Vacutainer) Sample on the GC3 or NGA}

After the headspace sample vial has been in the oven for $30 \mathrm{~min}$, remove the vial and inject the sample into either the GC3 or NGA gas chromatograph. Inject the vacutainer as soon as possible after collection.

The overall sequence for the operation is to set up the correct sample identifier (ID), run the headspace sample (vacutainer) on either GC3 or NGA, look at the chromatographic trace and correct it if necessary, print a report file, and send the data to the Janus database (see "Appen$\operatorname{dix}$ B," p. 17).

At the HP ChemStation computer, select the correct GC for analysis by toggling between the two open programs, GC3 (online) and NGA (online), on the command bar.

The procedure to analyze a sample is almost the same for GC3 and NGA. Proceed as follows:

1. Make sure the Method and Run Control windows of the HP ChemStation software are open. In the upper menu, select Run Control and then select Sample Info. This will bring up the screen to enter the sample ID and file names.

2. Change the file name (Signal 1) to the appropriate name, for example, "1H5HS.D" for Core 1, Section 5, headspace sample, or "1H5VAC.D" for Core 1, Section 5, vacutainer sample. Enter either $\mathrm{H}, \mathrm{X}$ or $\mathrm{R}$, depending on the coring technique.

3. Type the sample ID in the comment field in the following format: "1751075A1H5W0.0-5.0HS" for headspace analysis or "1751075A1H5W0.0-5.0VAC" for vacutainer analysis. These numbers and letters represent the leg (175), site and hole $(1075 \mathrm{~A})$, core and section (1H-5), working half of the core $(\mathrm{W})$, sampled interval $(0.0-5.0 \mathrm{~cm})$, and type of sample (HS or VAC).

4. Click on OK.

5. Inject $5 \mathrm{~mL}$ of headspace gas while keeping the flow control between 30 and 40 units, and hit the START button on the GC.

When the GC run is done, the analysis must be checked for accuracy. First, check the numbers on the screen printout, then CLOSE the printout and go to the View menu and select Data Analysis to access the Data Analysis window and look at the GC chromatogram. To modify the peak integration, first verify that the software is in integration mode and not calibration mode, and then reintegrate using the following four buttons:

1. The zoom in and out button, to enlarge or reduce a chosen chromatogram.

2. The $\mathrm{X}$ button, to delete chosen peak area integration information.

3. The integral button, to reintegrate a peak area. To do so, first delete the peak (using the X button) then use the mouse and draw a new baseline. When the mouse is released, the peak is automatically integrated.

4. The split peak button, used to split a double peak at the valley. 


\section{A. Pimmel and g. Claypool

After correcting the chromatogram, go to the Report menu and select Print Report. The report will print on the screen. From the report, manually write down the values for $\mathrm{C}_{1}$ to $\mathrm{C}_{3}$ on the gas analysis clipboard. At a later date, these values can be used to be entered in an Excel spreadsheet and worked on at your leisure.

For NGA analysis, proceed as described above while performing the additional step of checking both the TCD and FID chromatograms, separately. To do so, in the Data Analysis window under the File menu, select the last file run, making sure to select only one signal type, either TCD or FID, and reintegrate the chromatogram for a particular signal if needed. Print the report.

If a peak of interest has not been integrated, its retention time may have shifted. Go into calibration mode (accessed by clicking on the Balance button in the Data Analysis window) and change the retention time of the peak to the new appropriate retention time by typing its new value in the calibration table. DO NOT use any of the calibration buttons!

Once a report has been printed on the screen, the data is usually ready to be sent to the Janus database. See "Appendix B," p. 17. 
APPENDIX B

\section{Transfer of Gas Data to the Janus Database}

Each time a GC run is finished and the report printed on the screen, one of the following messages will appear on the white command line at the bottom of the Method and Run Control window of the HP ChemStation. For GC3: "CSV File C: \HPCHEM \GC3\DATA \JANUS \ GC3030.CSV," and for NGA: "CSV File C: \HPCHEM \NGA\DATA JANUS \NGA030.CSV." CSV files are created by a postrun macro embedded in the GC methods. The CSV files are used to transfer the data to the Janus database. If a CSV message does not show up after a run is finished, the macro needs to be reactivated. In the command line, type "MACRO GC3_CSV.MAC, GO" and press enter. Similarly, for NGA macro reactivation, type "MACRO NGA_CSV.MAC, GO" and press enter.

Every time that the chromatogram of a sample is reintegrated, a new CSV file needs to be created to incorporate the changes. To create a new CSV for the reintegrated sample, print the report on the screen and in the command line type either GC3_CSV or NGA_CSV, depending on which instrument you used to performed the run.

To transfer the gas data to the Janus database, proceed as follows:

1. Make sure you are logged into the Janus database. If not, log in as chem 104, password $=$ chem 104 , and select Chemistry under the Applications menu and then Gas-Input/Edit Gas File Data. An Input/Gas File Data window will open.

2. Select File Input under Mode. Query the desired CSV file under Enter Input File. A screen appears that allows you to select the directory where the CSV files generated from GC3 or NGA are stored. The directory will either be: "C: $\backslash$ HPCHEM $\backslash \mathrm{GC} \backslash \backslash \mathrm{DA}$ TA \JANUS" for the GC3 or "C: $\backslash$ HPCHEM $\backslash N G A \backslash D A T A \backslash J A N U S$ " for the NGA. The data files will look like "GC3030.CSV" or "NGA030.CSV." Always scroll down to the latest, or largest numbered, data file (e.g., NGA033.CSV should be taken instead of NGA032.CSV). The GC program automatically assigns its latest run with the next sequential number;

3. Press Read File. The sample ID and data will be loaded, and a Status window will appear. If there is a verification problem, the error will appear in red instead of black. If everything is loaded properly, press Save Input to load the data into the database. 


\section{APPENDIX C \\ Basic Features of the GAR Program}

The GAR software allows you to see any of the gas element analysis results for an entire hole. It also is capable of plotting the $C_{1} / C_{2}$ and the $\mathrm{C}_{1} / \mathrm{C}_{2+}$ ratios. Also, the data is available to GAR the minute it is uploaded into the database, so that you can use GAR as a warning tool for undesirably low ratios of $\mathrm{C}_{1} / \mathrm{C}_{2}$.

To access GAR, double click on the GAR icon, enter chem 104 for the Username and Password, and select Janus as Host. The screen shown in Figure AF1 will appear.

\section{Selecting Data to Be Plotted}

GAR uses a standard graphical user interface. However, not all of the features in this screen can be accessed by using the keyboard. A mouse is necessary for any of the graphical controls that allow you to control the scales, resolution, or position of the plots.

\section{Graph Area}

The graph area is capable of displaying any of the results from gas element analysis for an entire hole. You will notice the y-axis of the graph area is labeled "Depth (mbsf)" (Fig. AF1). The y-axis is the depth of each data point, given in meters below seafloor (mbsf). The $\mathrm{x}$-axis is the measurement, as given by the by the gas analysis.

The graph area has a several sets of controls placed around it. These controls allow you to select the data to be displayed, modify program operation, and manipulate the display or plot. The graph controls, placed to the left of the graph, are explained in the following section. The operation controls, placed on the lower left corner of GAR's screen, are explained in the section after that.

\section{Graph Controls}

The graph controls allow you to select the data you wish displayed on the graph (Fig. AF2).

To select the data to be plotted, follow these steps:

1. Select the hole for which you wish to obtain a plot. This is done by clicking on your selection from the list of holes with the mouse. You will notice the "* Current" option in the list of holes. This option automatically finds what the current hole is in the database. This may or may not be the first hole in the list, depending on whether the ship is drilling at a previously visited site.

2. Select the data type you wish to display. This is done by clicking on your selection from the list of data types.

One of the display types available is the "Element Table." This table will display the actual numbers as shown in Figure AF3. The resulting table shows one sample per row, and after the sample ID, it shows the depth and a column for each of the elements. Unfortunately, there is not enough room on the screen to display all the information. By default, the program will display the top left portion of the table. To the right
AF1. GAR graph area, p. 26.

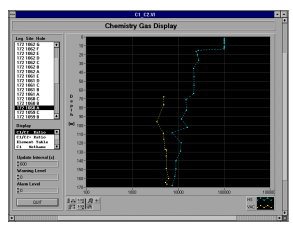

AF2. GAR data selection, p. 27.

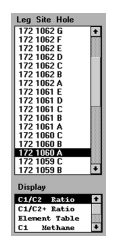

AF3. GAR element table, p. 28.

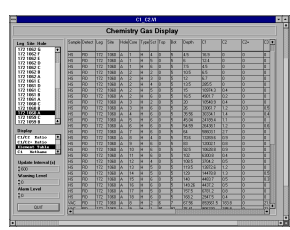




\section{A. Pimmel and G. Claypool}

and below the table, there are scroll bars that you can use to see the rest of the information. To do this, click on the scroll bar with the mouse, hold the mouse button down, and move the mouse in the direction you would like to see more data.

\section{Modifying Program Operation and Alarms}

GAR allows you to specify several things about how it operates. These include the frequency with which it should update itself from the database, the level of the selected gas element below which it should give a warning, and the ratio below which it should give an alarm.

\section{Update Interval}

Every so often, GAR updates itself from the database. This prompt lets you determine how often this should happen. In the example shown in Figure AF4, the user has chosen an update interval of 600 s. This means that every $10 \mathrm{~min}$, GAR will query the database for the data the user has chosen to display. If any new data has been added or any changes made during those $10 \mathrm{~min}$, GAR will receive the updated data. GAR will update the displayed graph or element table.

\section{Warning Level}

When GAR gets the requested data from the database, it checks every value against the number in the Warning Level prompt. If any value for the displayed data goes below the Warning Level value, GAR will display a small yellow message on the top right of the graph, and it will cause the computer to beep. Please note, if you want GAR to warn you of a low $C_{1} / C_{2}$ ratio, you must select $C_{1} / C_{2}$ to be displayed. The data displayed is what gets checked against the warning level.

\section{Alarm Level}

This works exactly like the Warning Level. However, if any of the data goes below the Alarm Level, GAR will display a bigger red message in the middle of the graph and it will start beeping continuously. Again, you must select the $C_{1} / C_{2}$ display if you want GAR to give an alarm for low $\mathrm{C}_{1} / \mathrm{C}_{2}$ ratios.

\section{Exiting GAR}

To exit GAR, click on the exit button located at the bottom corner of the operation controls.
AF4. GAR update, warning, and alarm entry, p. 29.

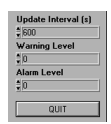




\section{A. Pimmel and g. Claypool

PUBLISHER'S NOTES

Material in this publication may be copied without restraint for library, abstract service, educational, or personal research purposes; however, this source should be appropriately acknowledged.

Pimmel, A., and Claypool, G., 2001. Introduction to shipboard organic geochemistry on the JOIDES Resolution. ODP Tech. Note, 30 [Online]. Available from World Wide Web: <http://www-odp.tamu.edu/publications/tnotes/tn30/INDEX.HTM>. [Cited YYYY-MM-DD]

Distribution: Electronic copies of this publication may be obtained from the ODP Publications homepage on the World Wide Web at http://www-odp.tamu.edu/publications.

This publication was prepared by the Ocean Drilling Program, Texas A\&M University, as an account of work performed under the international Ocean Drilling Program, which is managed by Joint Oceanographic Institutions, Inc., under contract with the National Science Foundation. Funding for the program is provided by the following agencies:

Australia/Canada/Chinese Taipei/Korea Consortium for Ocean Drilling

Deutsche Forschungsgemeinschaft (Federal Republic of Germany)

European Science Foundation Consortium for Ocean Drilling (Belgium, Denmark, Finland, Iceland, Ireland, Italy, The Netherlands, Norway, Portugal, Spain, Sweden, and Switzerland)

Institut National des Sciences de l'Univers-Centre National de la Recherche Scientifique (INSU-CNRS; France)

Marine High-Technology Bureau of the State Science and Technology Commission of the People's Republic of China

Ocean Research Institute of the University of Tokyo (Japan)

National Science Foundation (United States)

Natural Environment Research Council (United Kingdom)

\section{DISCLAIMER}

Any opinions, findings, and conclusions or recommendations expressed in this publication are those of the author(s) and do not necessarily reflect the views of the National Science Foundation, the participating agencies, Joint Oceanographic Institutions, Inc., Texas A\&M University, or Texas A\&M Research Foundation. 
Figure F1. General scheme of the evolution of the organic fraction and the hydrocarbon produced.

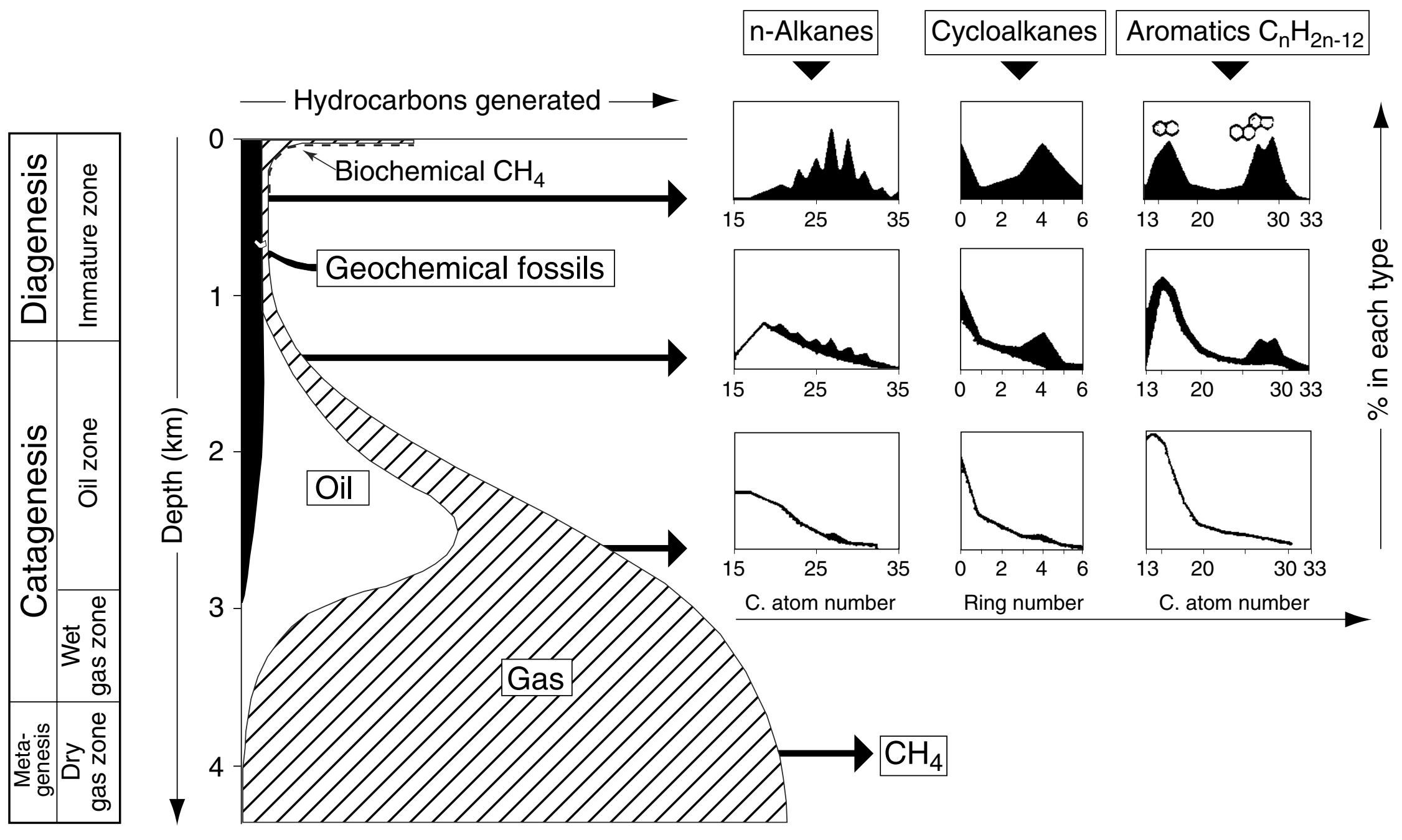


A. Pimmel and G. Claypool

SHIPBOARD ORGANIC GEOCHEMISTRY

Figure F2. $C_{1} / C_{2}$ ratios vs. sediment temperature diagram. TOC = total organic carbon.

Leg: Site: Hole:

Geothermal Gradient: $\quad{ }^{\circ} \mathrm{C} / \mathrm{km}$

Methane/Ethane $\left(\mathrm{C}_{1} / \mathrm{C}_{2}\right)$

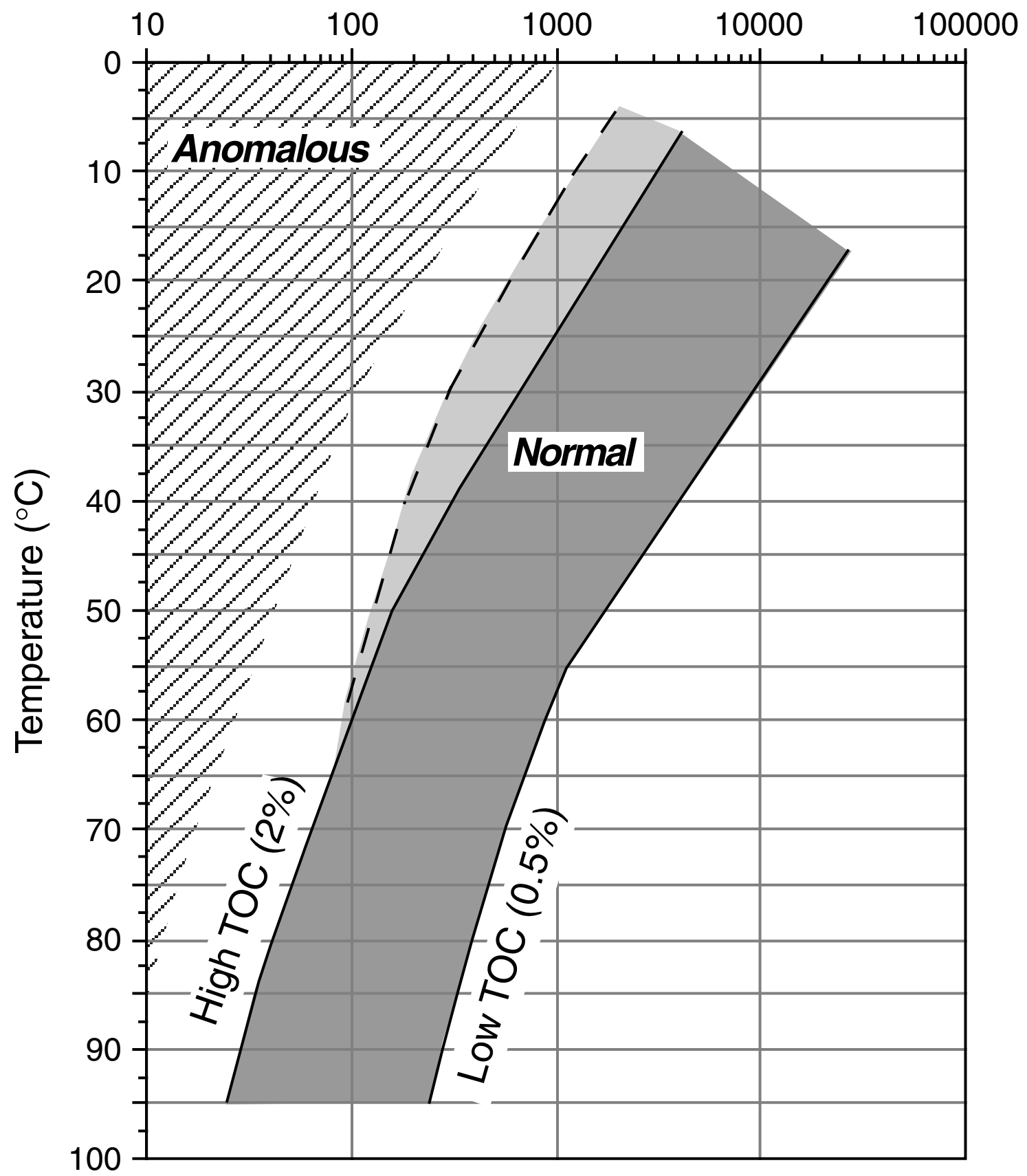


A. Pimmel and G. Claypool

SHIPBOARD ORgANIC GEOCHEMISTRY

Figure F3. $C_{1} / C_{2}$ ratios vs. sediment temperature diagram for Hole $909 \mathrm{C}$.

\section{Leg: 151 Site: 909}

\section{Geothermal Gradient: $88^{\circ} \mathrm{C} / \mathrm{km}$}

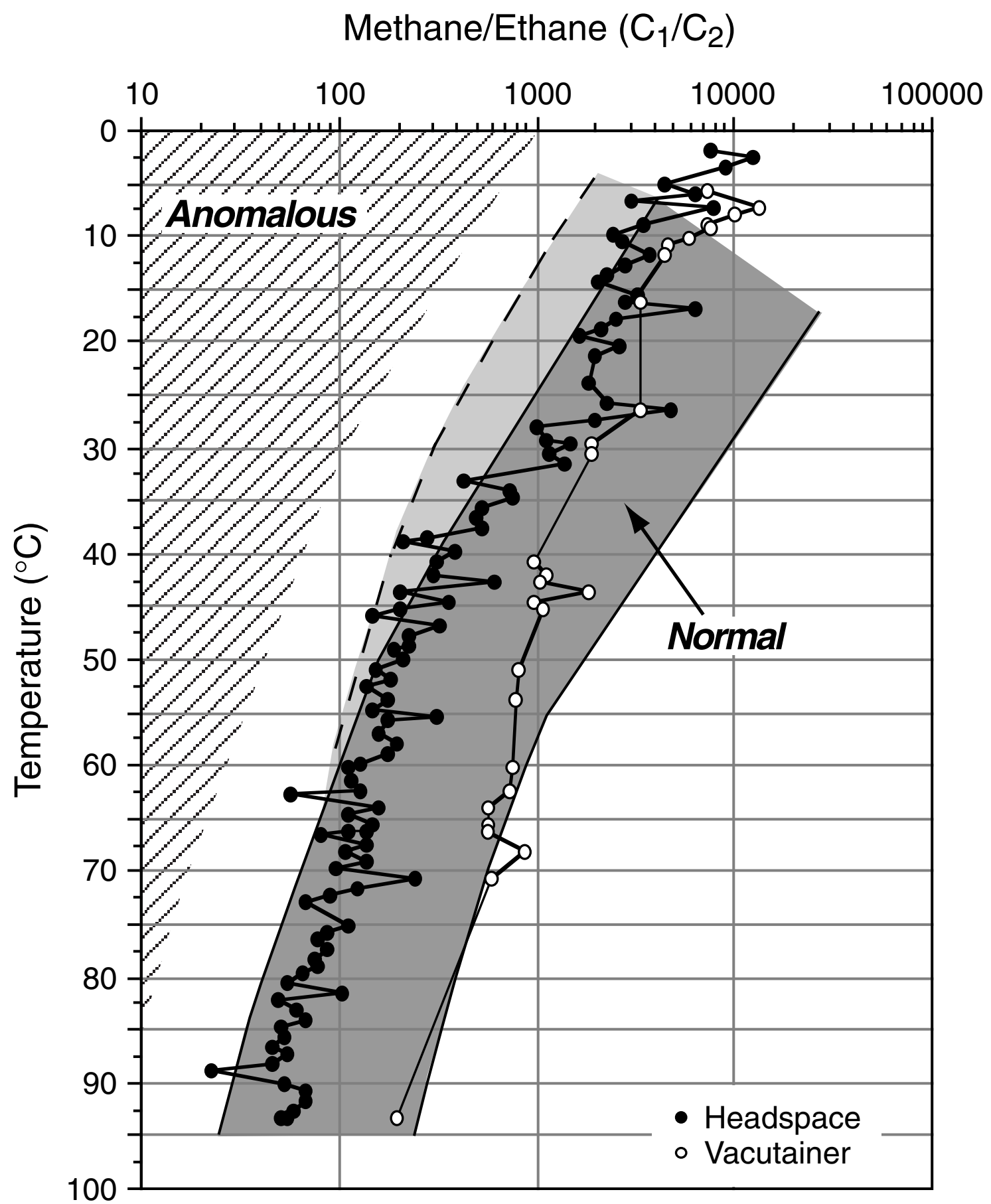




\section{A. Pimmel and G. Claypool}

Figure F4. Example of Rock Eval trace. HC = hydrocarbon.

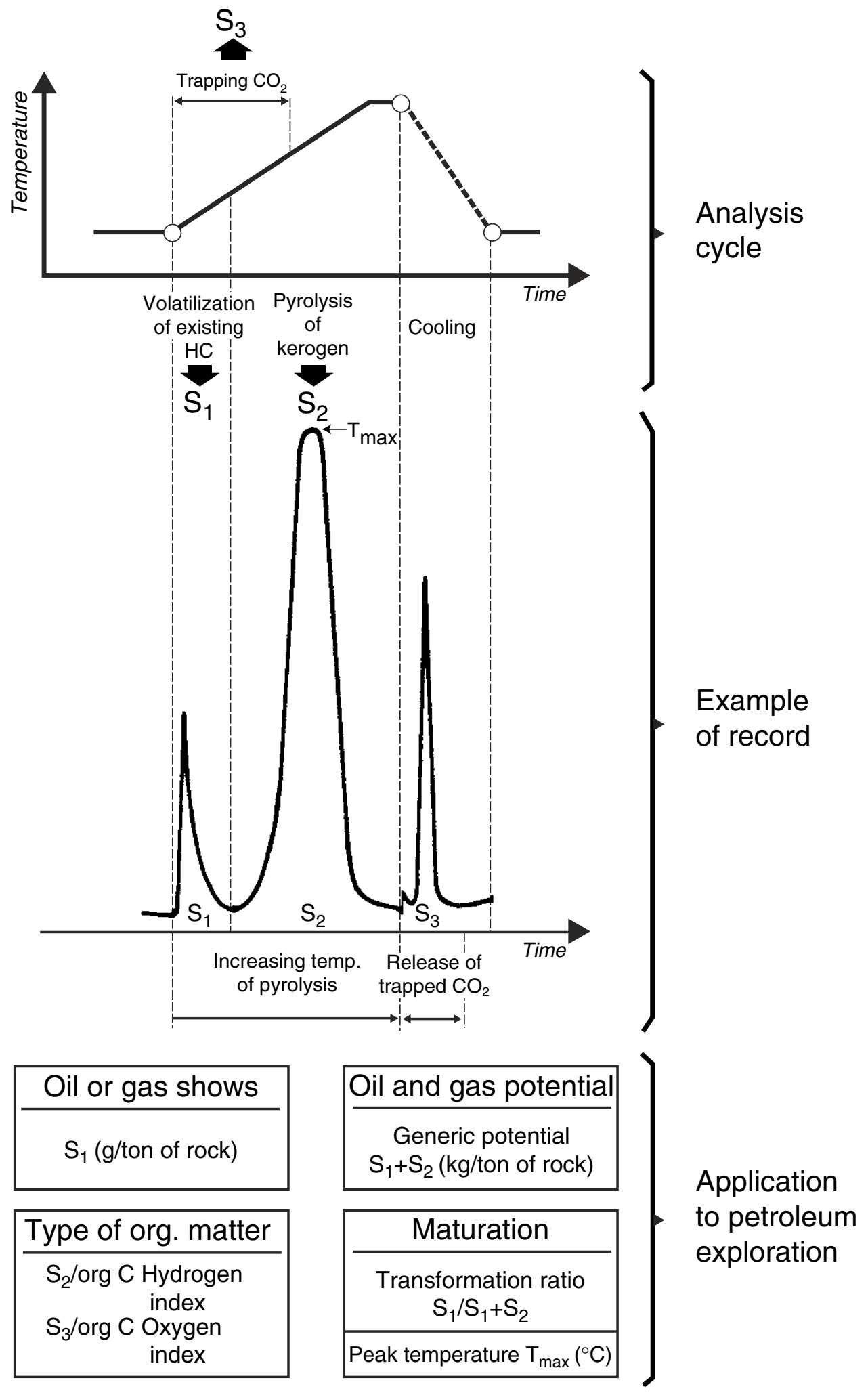


A. Pimmel and G. Claypool

SHIPBOARD ORGANIC GEOCHEMISTRY

Figure F5. Hydrogen index/oxygen index plot from Rock Eval pyrolysis data. TOC = total organic carbon.

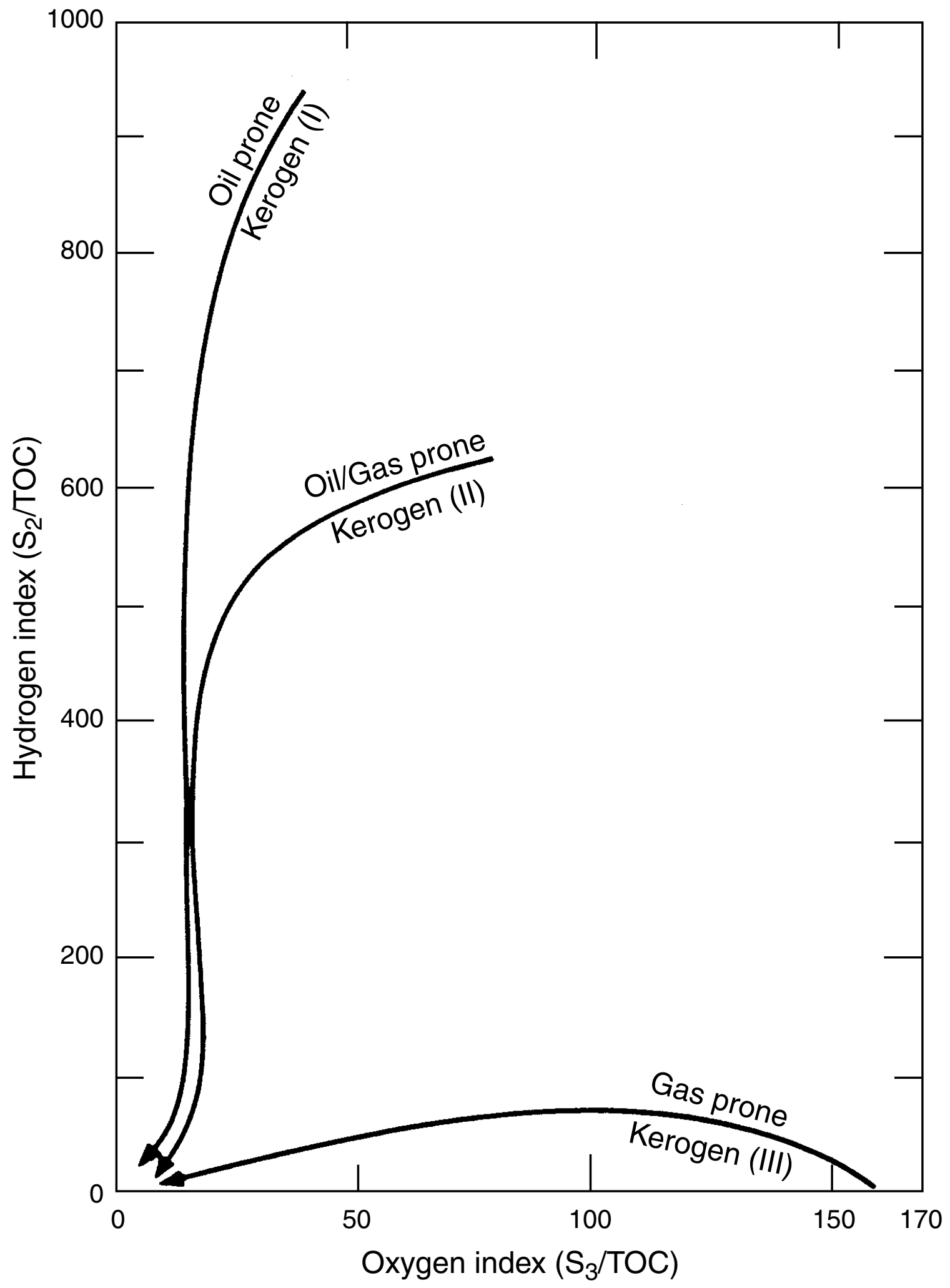


A. Pimmel and G. Claypool

SHIPBOARD ORgANIC GEOCHEMISTRY

Figure AF1. GAR graph area.

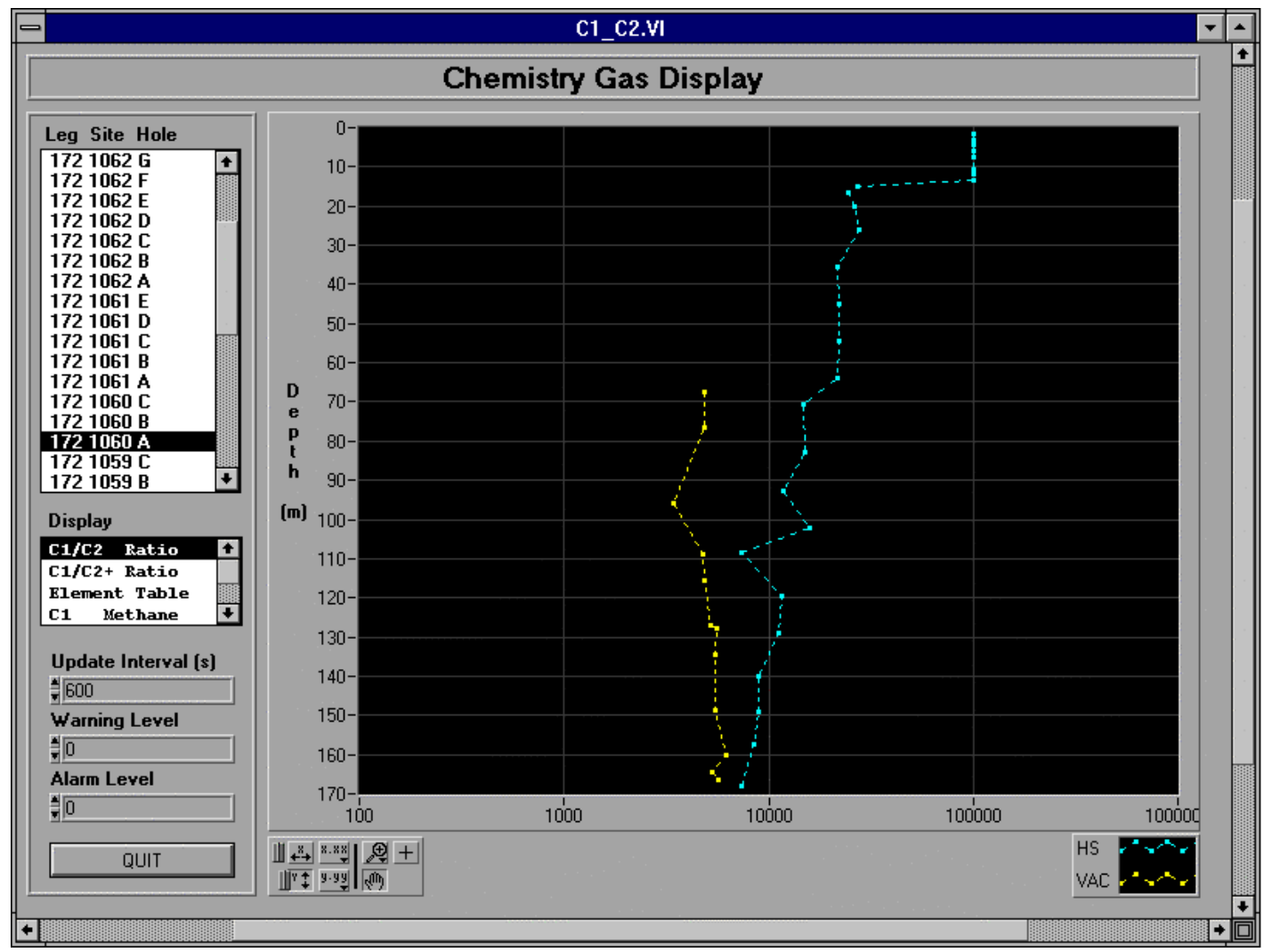


A. Pimmel and g. Claypool

SHIPBOARD ORGANIC GEOCHEMISTRY

Figure AF2. GAR data selection.

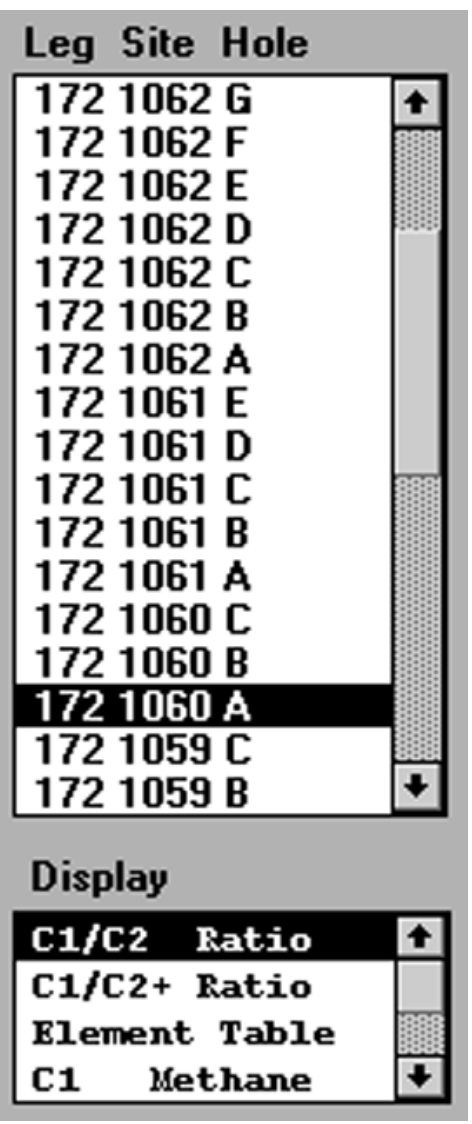


A. Pimmel and G. Claypool

SHIPBOARD ORGANIC GEOCHEMISTRY

Figure AF3. GAR element table.

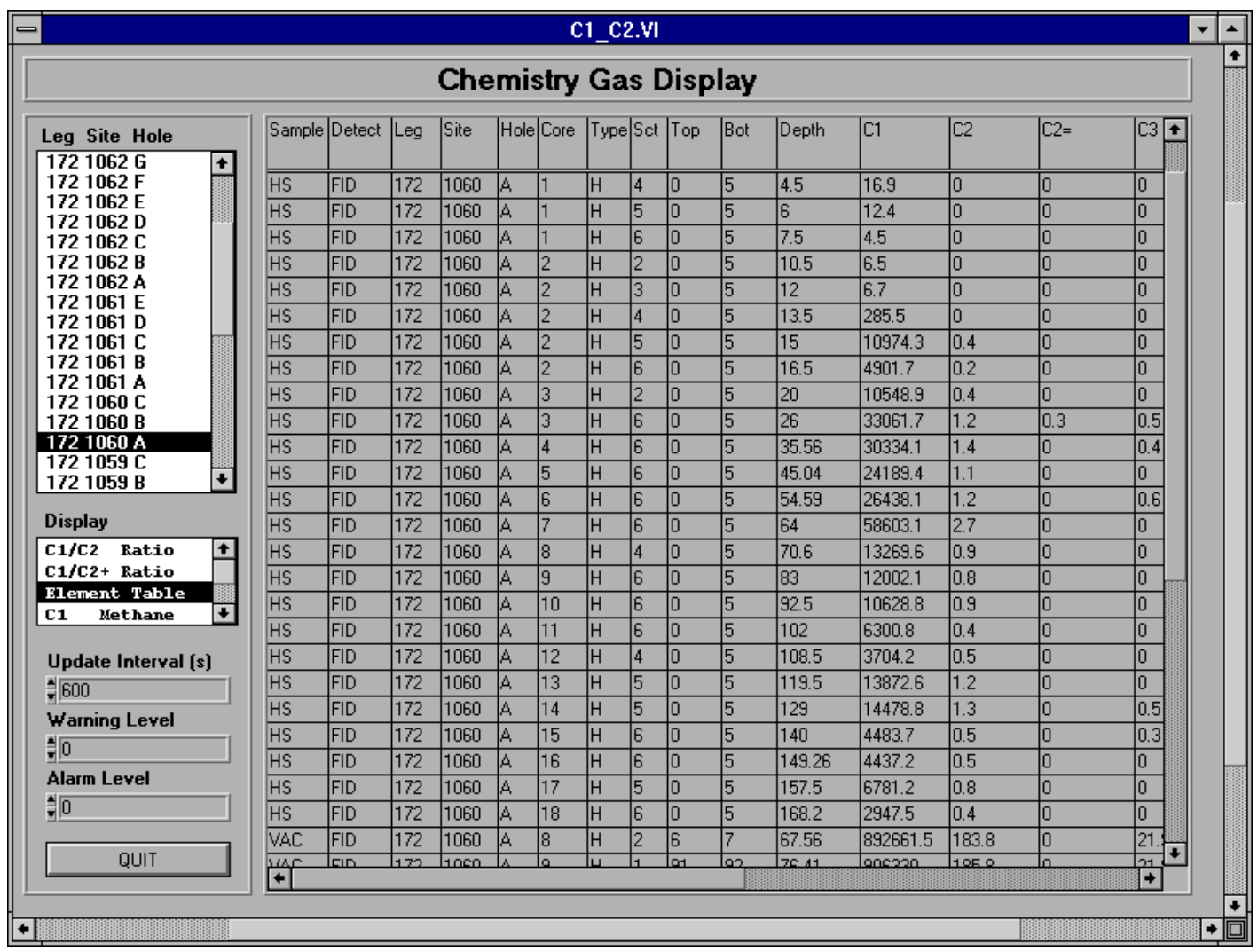


A. Pimmel and G. Claypool

Figure AF4. GAR update interval and warning and alarm levels.

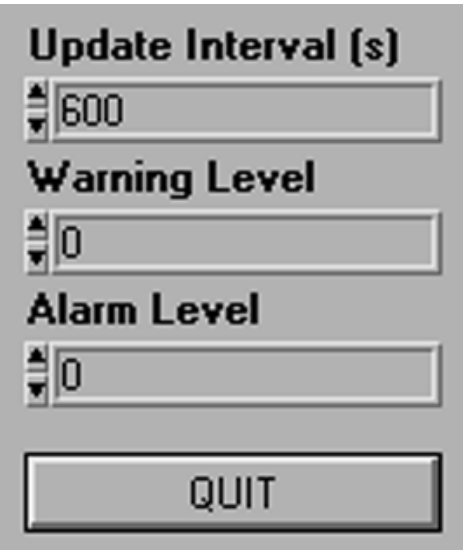

